\title{
Стара штампана књига у електронским базама података
}

\author{
Александра Драпшин \\ Библиотека Матице српске, Нови Сад \\ adrapsin@bms.ns.ac.rs
}

\begin{abstract}
Сажетак
Дуго година, раритетне публикације похрањене у збиркама библиотека и других установа, чуване у магацинима и затвореним металним ормарима, могли су да читају само посетиоци посебних, за то предвићених читаоница. Путем дигиталног окружења, оне су данас описане и претраживе у електронским каталозима и могу се прелистати у дигиталним библиотекама. Никад раније нису биле доступне тако великом кругу корисника. У раду се указује на могућности презентације раритета у електронским базама података, а посебно на њихово мећусобно повезивање. Дигитализација раритета не подразумева само пренос података у нове формате, већ омогућава квалитетнији, нови интерактивни истраживачки приступ. Као пример су послужила искуства Библиотеке Матице српске - Електронски

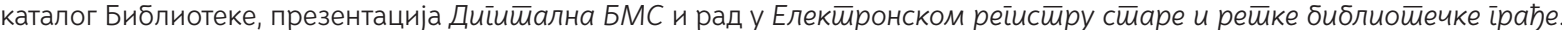
Приликом библиографско-каталошке обраде раритета, поред описа издања, велика пажња се посвећује примерцима. У раду се наводе врсте података које се уписују у поља напомена при електронској обради старих књига. Указује се и на могућности повезивања електронског каталога са дигиталним колекцијама.
\end{abstract}

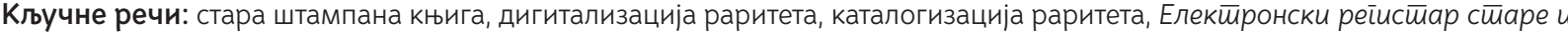

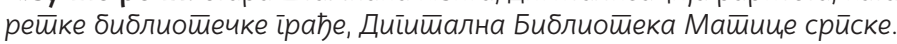

\section{Увод}

Рукописна и стара штампана књига својим садржајем, обликом писма, нормом правописа, језичким и текстолошким одликама, украсима и ликовним орнаментима, начином повеза и материјалом корица и листова, преносник је садржаја културе протеклих времена. Функција књиге као медија јесте да кроз димензију времена чува и преноси „информације о прошлости једног друштва, његовим успонима и падовима, вредностима и идеалима. Комуникација у димензији простора обезбеђује функционисање друштва, док комуникација у димензији времена обезбеђује континуитет културе". ${ }^{1}$

У настојањима да сачувају, истраже, опишу и презентују поверено им духовно наслеђе, библиотеке дефинишу и себе. Својим одговорним приступом, квалитетним, организованим и систематичним радом, преношењем професионалних вредности и знања на сваку нову генерацију стручњака изграђују и свој идентитет и идентитет целе професије библиотекара.

Развојем информационе технологије подаци о раритетним публикацијама постали су доступни јавности путем електронских каталога и дигиталних колекција на интернету. Формирањем дигиталних библиотека, корисници имају могућност да прелистају и прочитају целокупну садржину публикације, а библиотекари да каталошке описе о непотпуним публикацијама и издањима које је тешко идентификовати допуне разрешеним и потврђеним подацима.

Милица Андевски и Жељко Вучковић, Пролеїомена за критичку йеgаїоїију меgија (Вршац: Висока школа струковних студија за образовање васпитача „Михаило Павлов"; Нови Сад: Филозофски факултет, 2012), 7. 
У раду су приказане електронске базе података раритетне грађе које се формирају у Библиотеци Матице српске. Наведене су врсте података које се бележе у електронском каталогу. Указано је и на могућности повезивања различитих база раритетних публикација. Дигитализација ретких примерака не подразумева само пренос у нови формат, већ даје могућност за квалитативно нов, интерактивни истраживачки приступ. Као пример су послужила искуства Библиотеке Матице српске - Електронски каталог Библиотеке, презентација Диїишална БМС и рад у Елекйронском реїисйру кулишурних gобара.

\section{Специфичности обраде старих штампаних књига}

При сусрету са старим штампаним књигама и настојањима да се идентификују и опишу, наилази се на бројне тешкоће. Постоје карактеристике издања на које се мора обратити пажња. На пример, код инкунабула и књига на страним језицима 16. и 17. века врло често нема уобичајене насловне стране са основним подацима о наслову, ауторству, месту и години издавања и штампару. Подаци се морају потражити на другим местима. Нумерација листова или страна старе књиге може бити сложена, постоји више различитих нумерација, или су означене само свешчице, што у праћењу комплетности књиге и редоследа листова захтева посебну обазривост. ${ }^{2}$ Код старих књига чешће се наилази и на варијанте издања једне публикације које би требало бележити у опису.

Трагови времена видљиви су на књигама које се описују. Велики број публикација није до нас дошао у оригиналном издању у каквом је изашао испод штампарске пресе. Требало би описати примерке који нису комплетни, некад су само фрагменти, или чак један лист неке публикације. Књиге су током времена прекоричаване. Власници су, према својим потребама, спајали и укоричавали више издања или њихове делове у једну књигу. Идентификација књиге и њена обрада нарочито су сложене уколико недостају почетни и завршни делови публикације, илустрације и други додаци. Сви подаци о раритету бележе се у опису: комплетност, односно недостајући, волантни и другачије сложени листови, затим врста повеза и спајање више наслова у једну књигу. При овим сложеним пословима неопходно је консултовање штампаних библиографија и каталога, а данас су од велике помоћи електронски каталози и дигиталне збирке. Понекад је тек уз упоређивање сваког листа примерка са дигиталном копијом негде на интернету могуће обрадити раритет. И при томе је потребна пажња и опрез, јер се и при дигитализацији дешавају грешке, а дигитализован примерак не мора бити комплетан. ${ }^{3}$

Током времена, власници и читаоци књига оставили су на њима своје белешке. Рукописни записи, потписи, посвете, печати, екслибриси и старе сигнатуре изузетно су културно-историјско сведочанство. Казују о кретању књиге, промени власништва, њеној историји и судбини и извор су многих других података. Рукописни записи обавештавају о пожарима, ратним страдањима, временским катастрофама, политичким приликама, о свакодневном животу људи, о цени књиге, уља, вина, платна, хартије, о трговачким пословима, о дуговима које је неко направио или вратио, о путовањима, о давању деце „на“ школу, о предметима у школи, о вежбама из француског или неког другог језика, о математичком рачуну, о браковима и рођењима, па и о смрти. За стару књигу важне су и информације о начину како је она доспела у библиотеку. Сви ови подаци при детаљној каталошкој обради књиге постају претраживи корисницима електронског каталога библиотеке.

\footnotetext{
2 Детаљније о карактеристикама страних инкунабула, може се погледати: Светлана Вучковић, „Инкунабуле на страним језицима у Библиотеци Матице српске", Го дишњак Библиойеке Машиище срйске за 2013 (2014): 53-76.

${ }^{3}$ Светлана Вучковић, „Инкунабуле на страним језицима у Србији”, у Рукойисна и сшиара шишамйана књиїа: зборник раgова, ур. Душица Грбић, Светлана Вучовић и Александра Драпшин (Београд: Заједница матичних библиотека Србије; Нови Сад: Библиотека Матице српске, 2018), 100
} 


\section{Електронска обрада раритета}

У раду се наводе врсте података које се бележе у подручју напомена при електронској обради антикварне грађе.Указује се на могуће начине повезивања каталога са дигиталним копијама. Путем електронских каталога описана грађа може бити брзо и ефикасно претражива и презентована на квалитативно нов интерактивни начин. Обрада раритетних публикција одвија се уз поштовање међународног стандарда за опис антикварне грађе ISBD(A). Након главног каталошко-библиографског описа, који подразумева опис комплетног, идеалног примерка, за ову грађу значајно је подручје напомена. Специфична поља за обраду старе књиге у COBISS3 ${ }^{4}$ каталогизацији, која се користе у формату COMARC/B ${ }^{5}$ су следећа: 140, 141, 316-318, 321 и 481, 482. Корисна су и поља 620, 518 и 540.

Структура поља 140 се користи да се детаљније кодирају илустрације целе књиге, илустрације као прилога на целој страни, да се упишу технике њихове израде, да се унесу предвиђени кодови за врсту садржаја, књижевног облика и биографије, за подлоге књига и прилога, постојање водених знакова, штампарских и издавачких сигнета и орнаментних знакова - ово поље је део заједничког библиографског записа и преузимају га све библиотеке. Поље 141 користи се за кодиране податке о примерку - материјал и врста повеза, привези, очуваност повеза и књижног блока, уз податке о установи, сигнатури и инвентарском броју.

У подручје прве опште напомене 321, за старе штампане књиге, наводе се у скраћеном облику извори, односно одабрани каталози и библиографије са бројем описане јединице. Они су значајна помоћ при идентификацији издања старих књига.

Предвиђена поља за описивање примерака су - поље 316 Найомена о иримерку, 317 На-

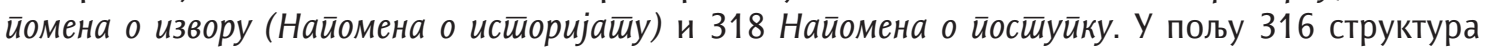
и редослед података су следећи: прво се указује на варијантске карактеристике, наводе се оштећења и стање комплетности према потпуном примерку, врста повеза, региструју се привези или приштампана дела. У пољу 317 бележе се подаци следећим редоследом: рукописни записи, печати, екслибриси, старе сигнатуре и доносе подаци у вези са набавком и временом инвентарисања. У пољу 318 наводи се Найомена о микрофилмовању. ${ }^{6}$ Поље 318 предвиђено је и за бележење података о поступцима конзервације и рестаурације и стању самих књига пре и после изведених поступака, који се засад не уносе. За претраживање су корисна поља $518-$ уносе се наслови савременим правописом и 620 Прешираживање йо местиу изgања, у потпоље \$а уносе се називи места издања. Уписивање података о привезима у електронским каталозима библиотека у систему COBISS.SR7 је неуједначено, а користе се поља 141, 316, 481 и 482 . Различито попуњавање напомена о примерцима може бити прихватљиво, због тога што оне нису део библиографског записа који је заједнички за све библиотеке у систему. ${ }^{8}$

За повезивање записа рукописних и старих штампаних књига са дигиталном копијом користи се потпоље \$u поља 856 са вредностима индикатора 41 - Елекйронска верзија. Тим путем копија се повезује са целим библиографским записом у бази. Поље 856 понавља се за сваку копију у свим случајевима, када је она из исте или из других библиотека.

\footnotetext{
${ }^{4}$ Кооперативни онлајн библиографски систем и сервиси - трећа генерација програмске опреме, преузето 24. 3. 2021, http:// sr.cobiss.net/.

${ }_{5}^{5}$ Формат машински читљивог записа за опис и размену библиографских података у систему COBISS заснован на формату за библиографске податке UNIMARC. - COMARC/B Format, preuzeto 24. 3. 2021, http://obrazovanje.vbs.rs/EntryFormDesktopDefault.aspx?tabid=38\&type=manual\&manual=1_Comarc_B_svn.

6 Подаци се уписују у поља наведеним редоследом у Електронском каталогу Библиотеке Матице српске, преузето 15. 2. 2021, https://plus.sr.cobiss.net/opac7/bib/search.

7 Систем узајамне каталогизације у Србији на платформи COBISS.

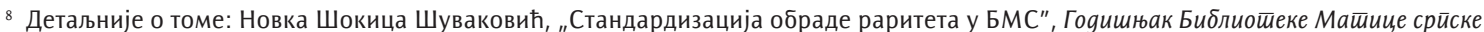
за 2016 (2017): 111-125 и Новка Шокица Шуваковић, Употреба UNIMARC формата за описивање рукописних и старих штампаних књига", у Рукойисна и стиара шишамйана књиїа: зборник раgова, ур. Душица Грбић, Светлана Вучовић и Александра Драпшин (Београд: Заједница матичних библиотека Србије; Нови Сад: Библиотека Матице српске, 2018), 312-323.
} 
Формат COMARC/B који се примењује у COBISS3 каталогизацији, не садржи све промене које су укључене у треће издање UNIMARC-а из 2008, ${ }^{9}$ а од значаја су за квалитетније представљање раритетних публикација. У формату UNIMARC, ${ }^{10}$ већ тада је предвићен унос URL адреса у поља напомена 316-318, 320 и 321, у потпоље \$u. Примењивање допуна у формату отворило би простор за нов приступ повезивању примерака књига, односно њихових делова са дигитализованим објектима на које се односе. Садржавали би везе до дигиталних верзија оштећене странице, одабраног повеза, потписа, печата, рукописног записа, екслибриса и других карактеристика из историјата примерка. ${ }^{11}$

Записи чланака приликом аналитичке обраде старих периодичних публикација такође могу имати везу са дигиталним примерцима. У Библиотеци Матице српске у запис чланка уноси ce URL адреса која води до одређене странице дигитализованог часописа. ${ }^{12}$ Пре посла обраде, наравно, претходи дигитализација одабраних бројева часописа. Овако су досад обрађени

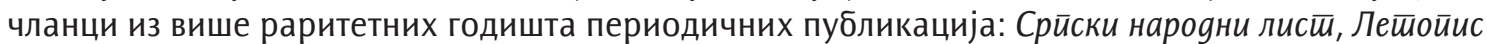

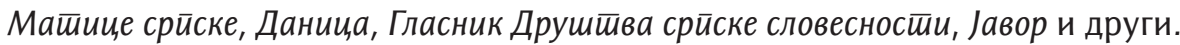

Формат UNIMARC за размену библиографских података доживео је и друге измене и допуне које могу бити од значаја за каталогизацију старих књига. Оне су објављене почетком 2018. године на веб-страници IFLA-е - све прихваћене промене од 2012. до 2017, без интегралног текста који је у припреми. У формат су додата и нова поља. ${ }^{13}$

Занимљива могу бити нова поља 703, 713 и 723 у која се уносе подаци о власништву, односно историјату примерка - 703 лична, 713 корпоративна и 723 породична имена. Структура тих поља иста је као у пољима 700, 710 и 720.

За унос података о месту и датуму везаним за историјат примерка направљена је спецификација поља 621. За повезивање са примерцима користи се потпоље $\$ 5$, а за повезивање унутар истог записа потпоље $\$ 6$. Поље 621 се повезује са напоменом 317 и именима у 7X3. То су случајеви када се у неком рукописном запису помиње и име и место, односно време.

Претраживи подаци о примерцима старих штампаних публикација, поред значаја за кориснике, могу бити велика помоћ библиотекарима при каталогизацији. Исти печат или рукописни потпис, уколико се појављује у више публикација, драгоцен је при рашчитавању недовољно јасних, а сличних примера и такође занимљив као извор за друга истраживања.

У структури формата UNIMARC начињен је значајан напредак, а примена проширеног формата довела би до детаљнијег описивања и повезивања ове специфичне грађе са дигиталним објектима. Од библиотекара зависи колико ће пажње посветити поновној обради и допуни записа и њиховом повезивању. Како истиче Новка Шокица Шуваковић: „Потребно је велику пажњу посветити усавршавању библиотекара - оних који ће учествовати у стратешким пословима, оних који ће бити специјалисти за обраду рукописа и старих и ретких публикација и свих библиотекара који обављају послове каталогизације и дигитализације. Са сигурношћу се може закључити да је повећана потреба за стручњацима који се баве старом и ретком библиотечком грађом."14

\footnotetext{
9 UNIMARC Manual - UNIMARC Bibliographic, 3rd edition (München: K. G. Saur, 2008).

${ }_{10}$ Universal Marc Format, preuzeto 15. 2. 2021, https://archive.ifla.org/ubcim/p1996-1/unimarc.htm.

11 Шокица Шуваковић, „Употреба UNIMARC формата...", 316-320.

12 „Извештај о раду Библиотеке Матице српске у 2019. години”, Гоgишњак Библиошеке Майице срйске за 2019 (2020): 10.

13 Шокица Шуваковић, „Употреба UNIMARC формата...", 318.

14 Исто, 322.
} 


\section{Дигиталне библиотеке раритета}

Дигитализацијом раритетних публикација и презентацијом дигиталних колекција у виртуелном окружењу књиге се из затворених, измештају у лако и брзо јавно доступне просторе. Поред функције очувања и заштите, универзалан приступ културном наслеђу један је од основних циљева наведен у препорукама и документима за дигиталне садржаје. Све веће библиотеке и код нас и у свету оформиле су дигиталне библиотеке у којима представљају своје најзначније колекције, а постоје и специјализоване базе података антикварне грађе. По броју дигитализованих примерака раритета у Србији, највеће су дигиталне збирке Народне библиотеке Србије, Библиотеке Матице српске и Универзитетске билиотеке „Светозар Марковић” у Београду.

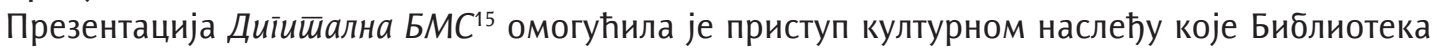
Матице српске поседује научним истраживачима и широј јавности. Веб-страницу годишње посети близу 30.000 корисника са свих континената. ${ }^{16}$ У бази су најбројније старе штампане књиге и периодика.

Дигиталне библиотеке садрже колекције дигиталних докумената који су описани одговарајућим метаподацима и заједно чине дигиталне објекте. За стару књигу дигитални документ је копија оригиналног примерка. Неопходни су и алати за њихово чување и претраживање, прегледање и преузимање.

У Диіиталној БМС представљен је најкомплетнији и најбоље очуван раритетни примерак из фонда Библиотеке. Уколико је потребно, дигитална колекција допуњава се и другим копијама, како би се реконструисало потпуно издање или да се покажу значајне забелешке из историјата књиге. Метаподаци за раритетну грађу најчешће морају да се формирају приликом уноса, због тога што је она у електронском каталогу описана према $\operatorname{ISBD}(\mathrm{A})$ стандарду, према којем се поштује писмо публикације, користи се стара ћирилица и, као такви, нису адекватни за претраживање у дигиталним колекцијама. Наслови старе библиотечке грађе штампани грађанском и црквеном ћирилицом углавном се уносе савременим писмом. Места издања, издавача и штампара налазе се на публикацијама у различитим облицима, па је корисно као метаподатке усвојити њихове јединствене називе ради лакшег приступа и претраживања дигиталних објеката. ${ }^{17}$

Као што је наведено да се преко електронског каталога може приступити дигиталним копијама, тако је и дигитализоване примерке старе библиотечке грађе потребно повезати са електронским каталозима. Нови софтверски алати омогућавају и друге везе, на пример повезивање са публикованим описима грађе и научним и стручним радовима, што доприноси широј и потпунијој информацији о представљеним раритетима.

У презентацији Диїйална БМС, поред листања публикације, представљени су детаљнији описи дигитализованог примерка у штампаним каталозима Библиотеке Матице српске. Приступ је обезбеђен из записа дигиталног примерка преко линка. На тај начин представљена су истраживања о самој грађи. У описима инкунабула Библиотеке Матице српске, на пример, налазе се линкови према њиховим описима у светским каталозима инкунабула, а наведена је и копија са којом је вршено поређење приликом идентификације и обраде и веза са том дигиталном копијом.

Дигиталне колекције раритета, јавно доступне преко интернета, веома су значајне и за библиотекаре. Данас је скоро немогуће бавити се пословима идентификације и каталошко-библиографске обраде старих књига, а да се не консултују електронски каталози и дигиталне колекције библиотека у свету и у Србији и друге јавно доступне збирке.

\footnotetext{
15 Диїишална Библиоеиека Майиие срйске, преузето 21. 3. 2021, http://digital.bms.rs.

16 „Извештај о раду Библиотеке Матице српске у 2019. години”: 31.

17 Новка Шокица Шуваковић, „Дигитална БМС", Гоgишњак Библиоиеке Майице срйске за 2011 (2012): 131-132.
} 


\section{Електронски регистар старе и ретке библиотечке грађе}

Прописима у области старе и ретке библиотечке грађе донетим 2011. и 2013. године, ${ }^{18}$ као новина, предвиђено је да се Регистар културних добара, поред штампаног, води и у електронском облику. Пројекат Елекйронски реїисиар покренут је убрзо након доношења Закона о старој и реткој библиотечкој грађи и подзаконских аката из 2013. Као основа базе унети су по-

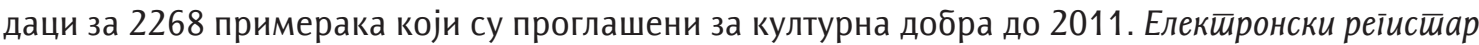
има своју интернет презентацију, ${ }_{19}^{19}$ која пружа могућност претраге културних добара по више параметара. Од тада, па до априла 2018. године, као предлог у бази је евидентирано преко 11.000 примерака. ${ }^{20}$

Закон из 2011. године донео је и друге новине. Послове од општег интереса по новим правним прописима, осим Народне библиотеке Србије која је задужена за територију целе Републике, обављају и друге библиотеке. На територији АП Војводине, послове заштите старе и ретке библиотечке грађе обавља Библиотека Матице српске и у јединицима локалне самоуправе 26 библиотека које је Решењем одредио министар културе и информисања за одређену територију. ${ }^{21}$ У послове заштите укључено је више актера, а електронско вођење регистара створило је услове за организованији и ефикаснији рад на пописивању и заштити културних добара у Републици Србији.

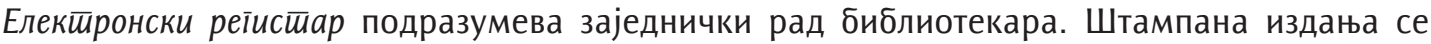
уносе једанпут, омогућено је преузимање записа. Поред уписивања предвиђених података о публикацији, постоји могућност да се унети запис повеже са електронском базом COBISS или БИСИС и путем хиперлинкова са дигиталним збиркама. Библиотека Матице српске повезује своје примерке са њиховим снимцима у бази Диіийална БМС и описима у штампаним каталозима који се такође налазе на веб-страници.

Елекйронски реіистиар већ сада пружа могућност да се у једној бази обједине бројни подаци о заштићеним публикацијама и њихове дигиталне копије, без обзира на власништво културног добра - да ли је то библиотека, институција, црквена и манастирска библиотека или приватно лице. Поред одређених мањкавости које има, дорадом софтверског решења могуће је испунити крајњи циљ Елекйронскої реїистира, а то је евиденција свих примерака старе библиотечке грађе у Републици Србији.

\section{Закључак}

Захваљујући технолошком напретку, културна добра, путем електронских каталога и дигиталних библиотека, данас су присутна у јавном простору и доступна широком кругу корисника. Антикварна грађа похрањена у магацинима, некад доступна малом броју читалаца у посебним читаоницама, данас је презентована путем електронског окружења великом броју потенцијалних читалаца широм света. Статистике показују да, на пример, старе књиге у Диіишиалној Библиошещи Машиище срйске прелиставају посетиоци са свих континената.

\footnotetext{
18 “Закон о старој и реткој библиотечкој грађи”, Службени іласник РС год. 67, бр. 52 (2011): 10-16; „Правилник о ближим условима и начину коришћења старе и ретке библиотечке грађе”, Службени іласник РС год. 69, бр. 22 (2013): 42; "Правилник о мерама техничке заштите старе и ретке библиотечке грађе”, Службени іласник РС год. 69, бр. 22 (2013): 42; „Правилник о садржини и начину вођења регистара категорисане старе и ретке библиотечке грађе", Службени іласник РС год. 69, бр. 22 (2013): 43.

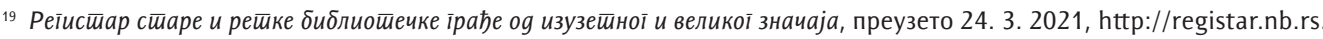

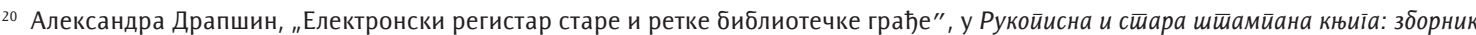
раgова, ур. Душица Грбић, Светлана Вучовић и Александра Драпшин (Београд: Заједница матичних библиотека Србије; Нови Сад: Библиотека Матице српске, 2018), 306

21 „Решење о одређивању библиотека које обављају послове од општег интереса у заштити старе и ретке библиотечке грађе”, Службени іласник РС год. 69, бр. 14 (2013): 15
} 
Поред тога, дигитално окружење не пружа смо прелиставање дигиталне копије, већ може да обухвати и обједини научна, стручна и католошко-библиографска истраживања раритета из прошлости, уједини их са савременим и понуди квалитативно нов истраживачки приступ.

Захтеви читалаца старих књига разноврсни су. Требало би одговорити на потребе, колико специјализованих научника из разних области, филолога, историчара књижевности и уметности, истраживача историјских прилика, палеографа, кодиколога, рестауратора, истраживача повеза или штампе, тако и најмлађих генерација којима је неопходна у образовне сврхе.

Библиотекари пре свега, али и остали чувари изузетних колекција, налазе се пред сложеним задацима, али и перспективом да успешно споје традицију и искуство прошлих генерација стручњака са новим технологијама и виртуелним окружењем. Може се закључити да ће у будућности бити неопходно више обучених стручњака како за послове биоблиографско-каталошке обраде, тако и за дигитализацију раритетне грађе и повезивање електронских база података.

Изграђујући однос према прошлости ствара се идентитет заједнице, идентитет библиотеке, али и професионални, па и идентитет сваког појединца. ${ }^{22}$ Помоћу виртуелног окружења, вредности које се чувају у библиотекама, затворене првенствено ради заштите, могуће је оживети и позвати истраживаче на њихово ново ишчитавање.

\section{Литература и извори:}

1. Andevski, Milica i Željko Vučković. Prolegomena za kritičku pedagogiju medija. Vršac: Visoka škola strukovnih studija za obrazovanje vaspitača "Mihailo Pavlov"; Novi Sad: Filozofski fakultet, 2012.

2. COMARC/B Format.Preuzeto 24. 3. 2021. http://obrazovanje.vbs.rs/EntryFormDesktopDefault. aspx?tabid=38\&type=manual\&manual=1_Comarc_B_svn.

3. Digitalna Biblioteka Matice srpske. Preuzeto 21. 3. 2021. http://digital.bms.rs.

4. Drapšin, Aleksandra. „Elektronski registar stare i retke bibliotečke građe”. U Rukopisna i stara štampana knjiga: zbornik radova. Urednice Dušica Grbić, Svetlana Vučović i Aleksandra Drapšin, 303-311. Beograd: Zajednica matičnih biblioteka Srbije; Novi Sad: Biblioteka Matice srpske, 2018.

5. Elektronski katalog Biblioteke Matice srpske. Preuzeto 15. 2. 2021. https://plus.sr.cobiss.net/opac7/bib/ search.

6. Elektronski registar stare i retke bibliotečke građe. Preuzeto 24. 3. 2021. http://registar.nb.rs.

7. „Izveštaj o radu Biblioteke Matice srpske za 2019. godinu". Godišnjak Biblioteke Matice srpske: za 2019 (2020): 9-55

8. Kooperativni onlajn bibliografski sistem i servisi. Preuzeto 24. 3. 2021. http://sr.cobiss.net/.

9. „Pravilnik o bližim uslovima i načinu korišćenja stare i retke bibliotečke građe”. Službeni glasnik RS god. 69, br. 22 (2013): 42

10. „Pravilnik o merama tehničke zaštite stare i retke bibliotečke građe”. Službeni glasnik RS god. 69, br. 22 (2013): 42

11. „Pravilnik o sadržini i načinu vođenja registara kategorisane stare i retke bibliotečke građe. Službeni glasnik RS god. 69, br. 22 (2013): 43.

12. „Rešenje o određivanju biblioteka koje obavljaju poslove od opšteg interesa u zaštiti stare i retke bibliotečke građe". Službeni glasnik RS god. 69, br. 14 (2013): 15.

13. Stokić Simončić, Gordana i Željko Vučković. Biblioteke i identitet. Pančevo: Gradska biblioteka Pančevo; Novi Sad: Filozofski fakultet Univerziteta u Novom Sadu, 2012.

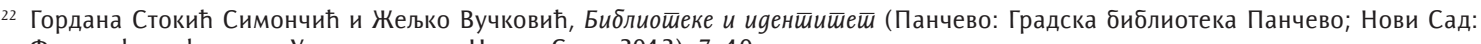
Филозофски факултет Универзитета у Новом Саду, 2012), 7-10.
} 
14. Šokica Šuvaković, Novka. „Digitalna BMS”. Godišnjak Biblioteke Matice srpske za 2011 (2012): 128-134.

15. Šokica Šuvaković, Novka. „Standardizacija obrade rariteta u BMS”. Godišnjak Biblioteke Matice srpske za 2016 (2017): 111-125.

16. Šokica Šuvaković, Novka. „Upotreba UNIMARC formata za opisivanje rukopisnih i starih štampanih knjiga". U Rukopisna i stara štampana knjiga: zbornik radova. Urednice Dušica Grbić, Svetlana Vučović i Aleksandra Drapšin, 312-323. Beograd: Zajednica matičnih biblioteka Srbije; Novi Sad: Biblioteka Matice srpske, 2018.

17. UNIMARC Manual - UNIMARC Bibliographic. 3rd edition. München: K. G. Saur, 2008.

18. Universal Marc Format. Preuzeto 15. 2. 2021. https://archive.ifla.org/ubcim/p1996-1/unimarc.htm.

19. Vučković, Svetlana. „Inkunabule na stranim jezicima u Biblioteci Matice srpske". Godišnjak Biblioteke Matice srpske za 2013 (2014): 53-76.

20. Vučković, Svetlana. „Inkunabule na stranim jezicima u Srbiji". U Rukopisna i stara štampana knjiga: zbornik radova. Urednice Dušica Grbić, Svetlana Vučović i Aleksandra Drapšin, 99-114. Beograd: Zajednica matičnih biblioteka Srbije; Novi Sad: Biblioteka Matice srpske, 2018.

21. „Zakon o staroj i retkoj bibliotečkoj građi”. Službeni glasnik RS god. 67, br. 52 (2011): 10-16.

\title{
Old Printed Books in Electronic Databases
}

\begin{abstract}
Summary
For many years, rare publications stored in libraries and other institutions, kept in warehouses and closed metal cabinets, could have been used only in special reading rooms. Today, in the digital environment, they are described and can be searched in electronic library catalogs and browsed in digital libraries. They have never before been available to such a large circle of users. The paper points out the possibilities of presenting rarities in electronic databases, and especially their interconnection. The digitization of rarities does not mean only the transfer of data into new formats but also implies a high-quality new interactive research approach. There are some examples from the Matica Srpska Library - its electronic catalog, Digital MSL, and its inputs in the Digital Register of Cultural Property. During the cataloging of rarities, in addition to the description, great attention is paid to the copies. This paper lists the types and order of the data entered as notes on the copies during the electronic cataloging of old books in the Matica Srpska Library. The possibility of connecting the electronic catalog with digital collections is also emphasized. The Digital MSL provides access to the cultural heritage possessed by the Matica Srpska Library for scientific researchers and the general public. In this database, digital publications are linked to the electronic catalog and descriptions in the printed catalogs of rare materials. All printed materials and manuscripts that have the status of cultural property in the Republic of Serbia are recorded in the Digital Register of Old and Rare Library Materials. The database provides a possibility of connecting the entered cultural property with the description in the electronic catalog and digital copy and thus combines numerous data on protected specimens in one place.
\end{abstract}

Keywords: old printed books, digitization of rarities, cataloging of rarities, Digital Register of Old and Rare Library Materials, Digital MSL 